\title{
Experimental Model of Teaching a Foreign Language at the HEE of the MIA in a Pandemic
}

\author{
Nailia Khairulina ${ }^{1}$ [0000-0003-3983-3627], Igor Kopotun 2 [0000-0002-2947-8599] \\ ${ }^{1}$ Luhansk State University of Internal Affairs named after E.O. Didorenko, Sievierodonetsk, Ukraine \\ ${ }^{2}$ HUSPOL, Czech Republic \\ *nailiakhairulina@gmail.com
}

\begin{abstract}
The article is devoted to the peculiarities of teaching a foreign language (English) in higher educational institutions of the Ministry of Internal Affairs during a pandemic. The author singles out an experimental model that significantly improves the acquired foreign language competence's effectiveness by future law enforcement officers and lawyers. The article focuses much attention on interactive technologies that enhance grammar, reading, writing, and listening skills. The paper considers distance learning as a form of organization of the educational process, within which its participants - teachers and students - interact remotely offline/online. The concept of "distance education" is interpreted as an opportunity to study and obtain the necessary knowledge remotely from the educational institution at any convenient time.
\end{abstract}

Keywords: distance education, experimental model, foreign language, methods of teaching.

\section{INTRODUCTION}

The first decades of the XXI century were marked by global reform of the pedagogical space. The rapid introduction of education innovations, including computerization, media technologies, networking, modified and adapted to new teaching methods and techniques. These changes activated the industry to search for useful teaching aids and models for effective education. Distance education technologies are currently developing the most dynamically. Therefore, one of the essential features of the modernization of higher education institutions is the introduction of distance learning, which significantly expands the educational content of a particular discipline and curriculum and improves academic service quality.

To date, it argued that the rapid development of the pandemic in the world has finally convinced teachers to implement all possible functions of distance education in full. Teachers' and students' work in 2020 proved that education without technologies is either impossible or limitedly useful. Thus, the most pressing issue for a foreign language teacher should be considered the following: how to most effectively use education technology to teach foreign languages to future lawyers.

Aiming to teach cadets and students of the University of Internal Affairs of a foreign language, namely -
English, the author proposes considering both positive and negative results of introducing the so-called experimental model of learning in a pandemic. Considering the role of technology and specific features of training students of legal specialties, this experimental model will focus on future lawyers' professional orientation.

As a semiotic component of distance education, the teacher understands that "the modern world almost wholly depends on advanced technology. Consequently, our life is fully influenced by modern technology-based devices like mobile phones, laptops, tablets, computers and so on. However, we cannot think a single day without the magical device mobile phone. Due to easy usage, people from all classes widely use it for many purposes" [1, p.33].

Now, the student has a great need to use the gadget for entertainment and gain new knowledge. Students are the most necessary asset of any school, college, or university [2]. Distance education allows people and society to participate fully in the development process by acquiring knowledge, skills, abilities, interests, competencies, and views. There is a need to "produce the best graduates who will become great leaders and provide enough human resources for social and economic 
development in any country in the world. It also ensures that the acquired skills and knowledge will allow people to increase their productivity and improve their quality of life" [3, p.48].

\section{RESEARCH METHODOLOGY}

But along with the need to learn, the dependence on gadgets is growing. This process is inevitable for absolutely all age groups of people receiving education, or, in other words, is a negative part of the global distance process. For example, this effect on school-age children is studied by $\mathrm{O}$. Ebenezer, who divides dependence into several stages as follows: "All children in the population were involved in the first phase of this study, both rural and urban-based. All participants were sent messages [persuasive texts (rendered as simple as possible for primary pupils to comprehend) and still images only], except those without emails or social media handles. Theirs (if they had any) or parents' emails or social media handles/contacts were collected for purposes not disclosed to them, and the persuasive messages were sent to them. Responses to messages were recorded as it was included in the messages that recipients were to acknowledge the receipt" [4, p.8].

As we can see, the analysis of positive and negative consequences of distance learning proves to be a promising methodology. A striking example is a work by M. Ames, "The Charisma Machine. The Life, Death, and Legacy of One Laptop per Child »[5]. The researcher forms a paradigm of positions that higher education institutions can take regarding the priority of technology implementation in education: charismatic, skeptical, and practical [4].

The charismatic position is to see technology as a determining factor in the development and existence of universities. From the point of view of a skeptical work, the technologicalization of education should be minimal. The social role of universities and students' socialization is more important than technology in education. Proponents of this position introduce the concept of "Luddite pedagogy" [6]. The practical work is moderate. Education needs to be improved, but significant progress is only gradual; one should not think utopian. Universities are adapting, but radical change will not happen [7].

Other authors, E. Al Haji and A. Azmani propose the creation of a unique ecosystem for the active educational process with the involvement of computer technology, which would not be addictive and would have the principle of "open data": "Indeed, this ecosystem is a space for exchanges and collaborations between several actors (pupils, students, parents, teachers, jobseekers, specialist consultants and professionals) aimed at helping young people, jobseekers or those seeking retraining find their way. Around easier. The proposed digital ecosystem is designed to facilitate management leadership based on an architecture that connects all the information systems of the various institutional players involved in leadership. It allows different actors to access it for different purposes (inform themselves, submit a request, use an electronic window, read practical advice, conduct tests, create a route, develop a project for the future, learn about trade, look for a player in training, form skills assessment, discuss and share information with others, consult statistics, see forecasts and many other uses). Such a digital ecosystem is based on the principle of "open data," thus promoting accessibility, re-use and dissemination, and universal participation" [8, p.2].

Distance form of education in the first decade of the XXI century. Ukrainian scientists O. Verenych, V. Hrytsenko, V. Kolos, and S. Kudryavtseva recognized distance learning as equivalent to full-time education. The researchers reflect all the components inherent in the educational process (goals, content, 31 methods, organizational forms, teaching aids), which are implemented through specific means.

But no matter how contradictory the feedback on distance education maybe today, the main thing remains that the opportunities and benefits of distance interaction between teacher and student significantly expand the temporal and spatial boundaries of learning, thus contributing to the intensification of this process. The criteria put forward by scientists to the distance form of education are as follows: "1) planned and systematic activities; 2) availability of special methodological techniques, communication, organizational and administrative measures; 3) implementation due to the latest technical means; 4) formation of a set of skills and competencies in students" [9, p. 6].

A practical foreign language lesson's distance format presupposes all the inherent attributes of full-time learning, such as group discussions, collective discussion of the material covered, live communication, etc.

To ensure a full-fledged educational process at a distance, in addition to technical tools, the teacher must have some professional and personal competencies that will interest, organize cadets and students at the initial stage and keep their attention until the final. Focusing on the class's main activities, the author concluded that a necessary condition for successful mastery of language material is creating tasks that would minimize the likelihood of plagiarism among students (copying, email during exercises, and the ability to consult on the Internet). Thus, the same type of task, which has several consecutive questions and answer options, become a priori irrelevant in the context of practical classes in English remotely.

An exciting alternative is the actualization of various language platforms to enhance such skills as reading, speaking, listening, and writing. The experimental model of English language teaching in the Ministry of Internal 
Affairs universities proposed by the author has constant and transitional elements. The stable components include platforms aimed at attracting technologies for grammar and listening. My English Lab and English Interactive Worksheets proved to be quite useful during the experiment. Emphasis should be placed on the effective complex "My English Lab" from Pearson. The educational complex consists of a textbook and an interactive application that thoroughly practices grammatical theory and practice.

The ability of the teacher to monitor the individual progress of the student contributes to the diversification of tasks and providing not general but personal recommendations to each. Moreover, this powerful resource allows you to practice speaking and to write online. The second application, which consolidates the acquired grammar skills, is the English Interactive Worksheets [8], a set of interactive grammatical tasks that each teacher has the opportunity to create according to the curriculum and assign assessment criteria and execution time. Given the author's approach and limited time, cadets and students focus on the task itself rather than looking for ways to write or find the Internet's answer.

The author of the article tried to create an experimental model for learning English in the HEE, including four interrelated stages: 1) enrichment; 2) activity; 3 ) creative; 4) value.

At each stage, all three pedagogical conditions were implemented: the use of necessary forms and means of communication by participants in the educational process; the combination of innovative and traditional learning technologies; interaction of teacher and cadets/students in the process of learning a foreign language using distance learning technologies.

Among the innovations widely used by teacherspractitioners of various disciplines is an interactive electronic poster, which, compared to conventional printing analogs, helps organize the educational process, especially distance learning.

It is a multidimensional didactic tool that provides multi-level work with a significant amount of material. Its use is possible at any stage of learning information while doing homework on a particular topic; it can also be part of a distance learning course in a foreign language.

The concept of "interactive poster" is separated from another - "multimedia poster" - the possibility of a nonlinear way of presenting the information. It has a high level of clarity, "reverse" action, "dialogue" with the user.

In modern pedagogical science, there are different visions and interpretations of the concept of "interactive poster":
- "electronic educational tool of a new type" [10, p. 43];

- "modern multifunctional learning tool that provides ample opportunities for organizing the learning process" [11, p.404];

- "electronic educational poster with interactive navigation, which allows you to display the necessary information: graphics, text, sound" [12, p. 405]);

- a means of presenting information, able to actively and variously respond to user actions, etc.

Much attention should be paid to the virtual notebook in terms of distance learning. This application allows the teacher to organize adequate support of students' learning activities during the study, consolidation, and generalization of program material, independent work. The use of interactive forms of work helps increase cadets' motivation to learn, develop their creative abilities, and form information and communication competence.

Besides, the use of virtual notebooks in a foreign language has several advantages, namely:

- the format of interaction between teacher and student acquires a new quality: the student becomes an active participant in the educational process, and the teacher - a facilitator;

- it can be used both during distance learning and in practical classes for independent work;

- facilitates the work of the teacher, saturates the activity with elements of creativity;

- activates cognitive activity, increases motivation;

- becomes an environment where structured work with different types of information and specific algorithms are proposed (search, select, process, store, broadcast);

- $\quad$ forms a creative approach to designing your product.

Transitional elements of the experimental model can be called work with electronic resources to present and activate lexical material for professional purposes. Thus, working with cards on the Quizlet platform proved to be a promising educational activity during English teaching.

Extracurricular work on learning a foreign language in distance education can take several different forms: from purely individual - improving language proficiency on the platform "Lingva Skills," and collective - holding round tables, webinars, discussions, meetings "English Hubs," etc.

\section{THE RESULTS OF THE STUDY}

The author proposes using the model of foreign language teaching with various educational platforms to reduce plagiarism and cheat off among students. The 
presence of constant applications for learning a foreign language, on the one hand, discipline the student, agree on some topics for study. Active use of additional resources: online cards, crossword puzzles, experience in evaluating each other's work, on the other hand, diversify the process of perception.

Thanks to this approach, the listener does not feel one-on-one with a soulless monitor. On the contrary, each applicant has an incentive to improve their knowledge and make progress in learning English, not for the sake of assessment in the record book but the sake of themselves and their future careers. This stimulus provides an active study of the professional glossary. There are two types of a glossary in the proposed experimental model, based on training requirements in the Ministry of Internal Affairs: English for law enforcement and legal English.

\section{DISCUSSION OF THE RESULTS}

Using a comprehensive experimental model of foreign language learning, we can conclude that this functionality is characterized by:

- dialogics - the interaction of teacher and students during the creation and presentation of an educational project using software applications (PowerPoint, Publisher, etc.) and online services (Glogster, etc.), which mainly motivates the teacher to use new methods and techniques of foreign language teaching ;

- easy to use - interactive poster and cards, for example, do not require installation, have a simple and straightforward interface;

- rich visual material - eloquent animations of phenomena and schemes, photographs and illustrations, which together give an advantage over other products and teaching aids;

- group and individual format of cooperation - allows to organize work with the whole group/platoon with the involvement of an interactive whiteboard or demonstration screen, and with each cadet/student separately on a personal computer;

Such tasks allow the applicant to master the theoretical material independently, test the theory in practice, activate their abilities, and think creatively. Simultaneously, the tasks develop self-discipline, independence, and the ability to allocate time rationally. Their consistent implementation and constant support of the tutor-teacher ensure the systematic acquisition of knowledge by students. Therefore, creating high-quality individual tasks for cases and their practical application in the educational process is a real way to intensify higher education and improve its quality.

The programs' educational material is presented as a logically completed separate fragment, which allows the lecturer to design practical classes per the defined purpose and objectives.

To successfully construct an experimental teaching model, the lecturer must learn to use targeted software applications and web 2.0 services. To create interactive posters, a lecturer can choose online services such as Glogster (which allows you to place text, graphics, and video, any element can be a hyper-call; has successful templates and blanks); Cacoo (provides the ability to design various classification schemes, where any part can become a hypervocation; contains different templates, auto shapes and allows you to add a finished image or draw it); Dabbleboard, Twiddla, Prezi, Projeqt, Linoit, SlideRosket, etc.

\section{CONCLUSIONS}

Thus, the distance learning process's effectiveness is achieved by using modern electronic devices and media in working with students/cadets, creating an educational communication environment as a result of a dynamic team and individual speech activities. In particular, such innovative teaching methods based on facilitation methods (techniques) as "world cafe," "open space," "basic facilitation," "dynamic facilitation," "going beyond," aimed at strengthening collective communicative interaction in the research process. Activities of students teach them to self-organization and co-creation. The use of case technology or the method of situational exercises in the context of distance education remains one of the priorities because it allows the teacher to organize students' personal growth as candidates for foreign competence.

Modern distance education is a relatively extensive knowledge transmission system due to various means and technologies. As a result - students receive the information necessary for its successful use in practice. The issues raised can be solved only through quality management of processes implemented in the university, creating an innovative environment in higher education a system of relationships based on organizational, methodological, psychological measures that ensure active involvement of innovation in the educational process.

Reforming the educational process in Ukrainian universities is primarily related to integrating education and information technology to create a single information environment. Modern education is impossible to imagine without high-quality and practical technologies of dissemination and exchange. The Internet is now the most convenient way to gain new knowledge. Web portals, websites, and blogs have become an integral part of educators' information space in implementing qualitatively other formal, non-formal, and informal education opportunities. Teachers use them both in everyday life and professional activities. 
Thus, the National Strategy for Education Development in Ukraine for the period up to 2021 states that among the "most acute problems hindering the development of education, do not provide a new quality of education adequate to the current historical epoch, is the slow introduction of innovative and information and communication technologies" [13].

\section{REFERENCES}

[1] Arifur Rahaman, Sabrina Tasnim, Md Sohag Hossain Majumdar, Emam Hossen and Md Rafiqul Islam (Rafiq) (2020), "A Comprehensive Study on Excessive Mobile Phone Use and Preventive Measures", International Journal of Modern Education and Computer Science, Vol. 12, No. 3, pp. 33-39. DOI: 10.5815/ijmecs.2020.03.05.

[2] Mushtak, I. and Khan, S.N. (2012), "Faktory', shho vply`vayut` na uspishnist` studentiv”, Global $n y$ `j zhurnal upravlinnya ta doslidzhen' biznesu, Vol. 12 (9), pp. 16-22.

[3] Sa'adatu Abdulkadir, Emmanuel Amano Onibere and Philip Oshiokhaimhele Odion (2019), "Assessment of Students' Academic Performance Using Admission Entry Requirements under the Computer-Based Test and PaperPencil-Based Test in Kaduna State University, Kaduna - Nigeria", International Journal of Modern Education and Computer Science, Vol. 11, No. 8, pp. 48-60. DOI: 10.5815/ijmecs.2019.08.06

[4] Odji Ebenezer (2020), "Influencing Children: Limitations of the Computer-Human-Interactive Persuasive Systems in Developing Societies", International Journal of Modern Education and Computer Science, Vol. 12, No. 5, pp. 1-15. DOI: 10.5815/ijmecs.2020.05.01

[5] Ames M. (2019), The Charisma Machine. The Life, Death, and Legacy of One Laptop per Child., MIT Press, 328 p.

[6] Reich J. Ed-Tech Mania Is Back. Utopia-minded tech gurus promise they'll solve all of academe's problems. They won't. The Chronicle of Higher Education, available at: https://www.chronicle.com/article/ed-tech-maniais-back?

[7] Essaid EL HAJI and Abdellah Azmani (2020), "Proposal of a Digital Ecosystem Based on Big Data and Artificial Intelligence to Support Educational and Vocational Guidance," International Journal of Modern Education and Computer Science, Vol. 12, No .4, pp. 1-11. DOI: 10.5815/ijmecs.2020.04.01. P.2)

[8] Karavans'ky'j, S. (2000), Prakty'chny'j slovny'k sy'nonimiv ukrayins'koyi movy' [Practical dictionary of synonyms of the Ukrainian language]. 2nd ed, Ukrayins'ka kny'ga, Kyiv, Ukrain, 480 p.

[9] English Interactive Worksheets, available at: https://www.liveworksheets.com/worksheets/en

[10] Arifur Rahaman, Sabrina Tasnim, Md Sohag Hossain Majumdar, Emam Hossen and Md Rafiqul Islam (Rafiq) (2020), "A Comprehensive Study on Excessive Mobile Phone Use and Preventive Measures", International Journal of Modern Education and Computer Science, Vol. 12, No. 3, pp. 33-39. DOI: 10.5815/ijmecs.2020.03.05.

[11] Shakhina, I.Yu. and Il'yina, O.I. (2015), "Practical dictionary of synonyms of the Ukrainian languageInteractive posters in educational activities. Problems and prospects of formation of the national humanitarian and technical elite", $z b$. nauk. pr., NTU «XPI», Vol. 42 (46), Xarkiv, Ukrain, pp. 403-412.

[12] Koropovskaya, V.P. (2014), "Create an interactive poster for the lesson. Internet services in education", ucheb.-metod. sb. matery`alov II Mezhdunarodnoj nauchno-prakty`cheskoj konferency`y 20 y`yunya 2014 goda y`matery`alov konkursa "Kalejdoskop servy`sov v obrazovany'y'», Y'ROOO, Omsk, Rossyia, pp. 138-146.

[13] Pro Nacional`nu strategiyu rozvy`tku osvity` v Ukrayini na period do 2021 roku, Ukaz Prezy`denta Ukrayiny vid 25.06.2013 № 344/2013, available at: http://zakon3.rada.gov.ua/laws/show/344/2013 